\title{
EFFECT OF COAL MINING ON SOIL NITROGEN DISTRIBUTION IN SEMI-ARID MINING AREA OF WESTERN CHINA
}

\author{
Dejun $\mathrm{YANG}^{1}{ }^{2}$, Yajun $\mathrm{ZHANG}{ }^{1}$, Xiuqin $\mathrm{CHEN}^{1}$ \\ ${ }^{1}$ School of Environment Science and Spatial Informatics, \\ China University of Mining and Technology, Xuzhou, China \\ ${ }^{2}$ Engineering Research Center of Ministry of Education for Mine Ecological Restoration, \\ China University of Mining and Technology, Xuzhou, China
}

Received 26 September 2018; accepted 03 June 2019

\begin{abstract}
Soil nitrogen is a key indicator of soil quality and plays a significant role for plant growth. Therefore, it is very important to study soil nitrogen distribution, especially in semi-arid area of western China. Fewer scholars paid attention to the effect on soil nitrogen due to coal mining in semi-arid mining areas of western China. In this paper, soil samples of different locations were tested in both the loess region and the aeolian sand region in the Daliuta mining area in Shaanxi Province. The impacts of mining subsidence on soil nitrogen were investigated. The soil nitrogen distributions between the loess region and the aeolian sand region were compared, and used the principal component analysis method to evaluate soil quality in semi-arid mining area. The results showed that the comprehensive score of soil quality in the loess region was as follows: the internal pulling stress zone (NLS) $>$ the external pulling stress zone (WLS) $>$ the compressive stress zone (YS) > the neutral zone (ZX). The content of soil total nitrogen in YS-zone was the lowest in the loess region. The loss of nitrogen increased with time in the mining area, in which the total nitrogen loss at the depth of $0-15 \mathrm{~cm}$ was $0.27 \mathrm{~g} / \mathrm{kg}$, and the alkaline nitrogen loss at the depth of $0-15 \mathrm{~cm}$ was $1.08 \mathrm{mg} / \mathrm{kg}$. In the aeolian sand region, the comprehensive score of soil quality was as follows: WLS $>$ FC (the non-mining zone) $>$ ZX $>$ NLS $>$ YS. The amount of soil nitrogen content in the loess region was larger than that in the aeolian sand region. It was found that for the loess region, the relationship between total nitrogen and nitrate nitrogen showed a significant positive correlation. It was also a significant positive correlation between ammonium nitrogen and alkaline nitrogen. In the aeolian sand region, there was a significant positive correlation between total nitrogen and alkaline nitrogen. There was no significant correlation among other nitrogen forms.
\end{abstract}

Keywords: coal mining, distribution, semi-arid mining area, soil nitrogen, the aeolian sand region, the loess region.

\section{Introduction}

Coal is the most important energy in China, accounting for about $75 \%$ of primary energy (Liu, Deng, Lei, \& Bian, 2015). In 2007, China's coal production exceeded onethird of the world's coal production, and more than $95 \%$ of China's coal production was exploited by wells (Bian, Inyang, Daniels, Otto, \& Struthers, 2010; Zhang, Hou, Han, Yang, \& Song, 2003). Shendong Mining Area, as one of China's important energy strategic bases, was proven reserves of 223.6 billion tons (Shi, Zhang, Hu, Ma, \& Yu, 2017a; Shi et al., 2017b). Subsidence zones are expanding with the development of coal mining. By the end of 2015 , subsidence areas increased to $314 \mathrm{~km}^{2}$, accounting for $26.2 \%$ of the Shenfu-Dongsheng coal field ( $\mathrm{He}$ et al., 2017). Underground mining is a widely used method for the exploitation of coal resources in China, however, this mode of resource extraction can form large underground mined out areas, which inevitably leads to severe land subsidence (J. M. Wang, P. Wang, Qin, \& H. D. Wang, 2017). The land area affected by mining subsidence is currently $700.000 \mathrm{~km}^{2}$ and is continually increasing at a rate of $130 \mathrm{~km}^{2}$ annually (Wang, Qin, $\mathrm{Hu}, \& \mathrm{Wu}, 2016 \mathrm{a}$ ). The strata movement, subsidence and flexural deformation caused by coal mining could change soil physical properties and indicators, and then change soil organic matter and nitrogen and other chemical properties and indicators in the subsidence area (Jing, Wang, Zhu, \& Feng, 2018). Coal mining subsidence can also accelerate soil erosion and underground leakage, which leads to a serious nitrogen loss in the soil, make the land more barren and influence the vegetation growth in the mining area (Jarašiūnas \& Kinderienè, 2016). Furthermore, soil nitrogen loss will

*Corresponding author. E-mail: yangdj81@163.com 
also cause other environment problem, such as eutrophication by the leaching of surface runoff and pollutants (Endale et al., 2017; Masilionyte, Maikštèniené, Velykis, \& Satkus, 2014; Kuter, Dilaver, \& Gul, 2014).

In the past few decades, most studies on soil nitrogen worldwide had focused on agricultural, forestry land, and et al. Cachoa et al. (2018) investigated the impacts of simultaneous production of biomass for biofuel and quality timber on soil nitrogen cycling in a poorly drained forest soil of eastern North Carolina, USA. Muhammed et al. (2018) estimated nitrogen changes and the nutrient fluxes exported from arable and grassland systems in the UK during 1800-2010. Iwaoka et al. (2018) analyzed physicochemical properties and inorganic nitrogen dynamics of soil samples from under tamarisk crowns and adjacent barren areas at three habitats in the summer and fall of 2014. Kolbe, Miller, Townsend-Small, Cameron, and Culley (2016) selected a chronosequence of six forested study sites to investigate whether nitrogen was affected by land-use history or forest community structure. Wang et al. (2016b) investigated the spatial variability of organic carbon and total nitrogen in the soils of a subalpine forested catchment at Mountain Taiyue, China. Liu et al. (2014) conducted a simple assessment on soil total nitrogen, available nitrogen and organic matter of paddy fields in South China. Zheng et al. (2018) examined the effects of plastic film mulching and fertilization on straw$\mathrm{N}$ distribution in farmland. Xiao et al. (2017) measured soil carbon and nitrogen after cropland conversion in a karst area, southwest China. However, fewer scholars have paid attention to the soil nitrogen distribution and the effect on soil nitrogen induced by coal mining in semi-arid mining areas of western China. Since soil nitrogen plays a crucial role in land rehabilitation and ecological restoration, it is significant to study soil nitrogen and the effect of coal mining on soil nitrogen in the mining area of western China.

Underground coal-mining results in severe land subsidence changes soil nutrient distributions. Different forms of soil nutrient are critical indicators of soil quality and play a key role for plant growth (Strachel, Wyszkowska, \& Baćmaga, 2017). Jing et al. (2018) researched the effects of land subsidence resulted from coal mining on soil nutrient distributions in loess region of China. Soil sampling points, taken from 4 different plots (one unmined plot, two subsided plots and one reclaimed plot), were collected in the loess region of China (Jing et al., 2018). To the best of our knowledge, up to now, no documentation is found to report the research on the impact of soil nitrogen in both the loess region and the aeolian sand region by coal mining.

In this study, the loess region and the aeolian sand region in Daliuta mining area were selected as the study sites. The aeolian sand is mainly composed of medium fine sand and fine sand. The structure has high porosity and good water permeability, but it has poor erosion resistance and is highly vulnerable to wind erosion. Loess is dominated by silt and has less clay content. It has higher strength and lower compressibility, poor soil and water conservation ability and is prone to subside (Sun, 2008). There are great differences between the two geomorphological features. The objectives of this study were to investigate the impact of mining subsidence on soil nitrogen, compare the soil nitrogen distribution between the loess region and the aeolian sand region, and use the principal component analysis method to evaluate soil quality in semi-arid mining area.

\section{Materials and methods}

\subsection{Experiment site and design}

The study sites are located in the Daliuta mining area at the northwest of Shenmu County, Shaanxi Province, and belong to the transitional zone between the northern margin of the Loess Plateau and the Mu Us Desert in northern Shaanxi. The landscape is characterized by aeolian sands and loess gullies (He et al., 2017). It is located between $39.1^{\circ} \mathrm{N}$ and $39.4^{\circ} \mathrm{N}$ latitude and $111.2^{\circ} \mathrm{E}$ and $110.5^{\circ} \mathrm{E}$ longitude. The elevation in this region varies from 1000 to $1500 \mathrm{~m}$ a.s.l (Bian et al., 2009). The area belongs to the typical temperate continental climate. The annual rainfall mainly concentrated in summer. It average rainfall ranges is between 251.3 and $646.5 \mathrm{~mm}$. The annual average temperature is $8.6^{\circ} \mathrm{C}$, and the annual average evaporation is as high as $1788.4 \mathrm{~mm}$, which is about 4 to 5 times of annual rainfall amount. According to our investigation, it is estimated that the groundwater depth is below -10 meters and the thickness of loess deposit is about 6-7 meters. The vegetation is monotonous and the vegetation coverage is only 3 to $11 \%$. The representative plant is Artemisia group, which forms a single dominant community in this area. More details can be seen in Yang, Bian, and Lei (2016).

According to the horizontal displacement deformation theory of mining subsidence, the surface was divided into the non-mining zone (FC-zone), the external pulling stress zone (WLS-zone), the internal pulling stress zone (NLS-zone), the compressive stress zone (YS-zone), and the neutral zone (ZX-zone) (He, Yang, Ling, Jia, \& Hong, 1991). We chose the loess region as one research area and set 6 sampling locations in WLS-zone, NLS-zone, YSzone, and $\mathrm{ZX}$-zone. The aeolian sand region was chosen as the other research area and set 7 sampling locations in FC-zone, WLS-zone, NLS-zone, YS-zone, and ZX-zone. The grid sampling method was adopted. The distance between two zones was about $70 \mathrm{~m}$, and sampling distance between two sampling locations in the same zone was about $20 \mathrm{~m}$ in the loess region, while the distance was about $35 \mathrm{~m}$ in the aeolian sand region. Details of soil sampling in the loess region was WLS-1 6, NLS-1 6, YS-1 6 and ZX-1 6, which can be seen in Figure 1. Details of soil sampling in the aeolian region was FC-1 7, WLS-1 7, NLS-1 7, YS-1 7 and ZX-1 7, which can be seen in Figure 2. Before sampling, the residues on topsoil were removed firstly. Soil samplings were collected on 
$0-15 \mathrm{~cm}$ soil depth. Each sample point in the study sites was taken for three parallels. A total of 24 soil samples for the loess region were obtained. For the aeolian region, we selected ZX-1, ZX-3, ZX-5, YS-1, YS-3, YS-5, NLS-1, NLS-3, NLS-5, WLS-1, WLS-3, WLS-5, FC-1, FC-3, FC-5 as the soil sampling locations. A total of 15 soil samples were obtained. In total, 39 soil samples were brought back to the laboratory for the measurements. The loess region was sampled in November 2015 and May 2016, while the aeolian sand region was sampled only in May 2016.

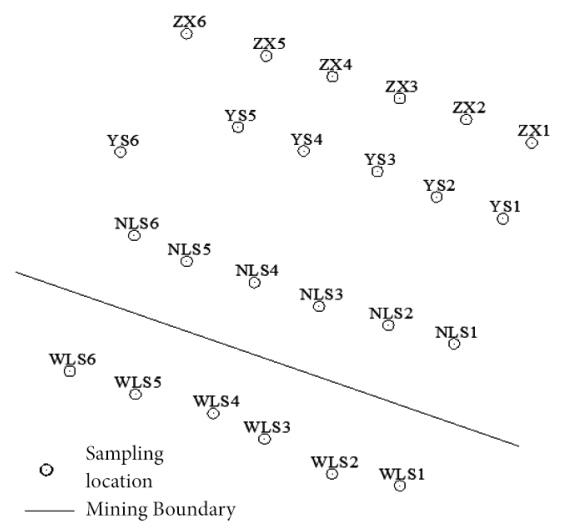

Figure 1. The layout of sampling points in the loess region

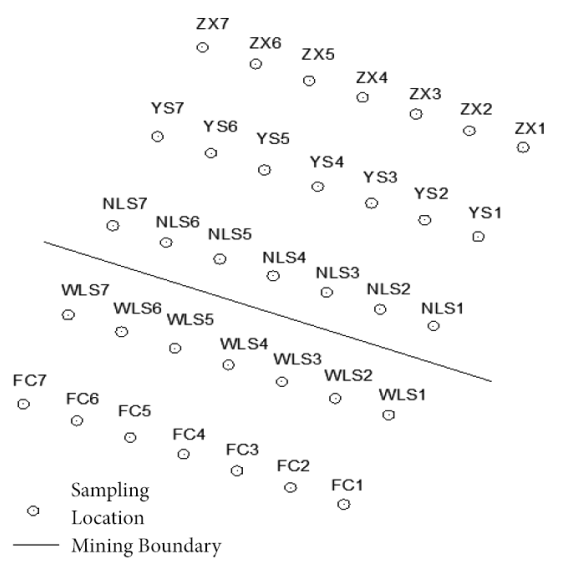

Figure 2. The layout of sampling points in the aeolian sand region

\subsection{Methodology}

Figure 3 shows the methodology for this study. Principal component analysis method (PCA) was used to comprehensively evaluate soil quality in the loess region and the aeolian sand region. PCA was used to determine the characteristic value and characteristic vector of the principal component of soil index by the factor analysis. According to the cumulative contribution rate of the principal component, the key principal components were selected, and the scores of the main components were calculated. Then the integrated soil quality indices value (IFI) of each sampling point was obtained by the comprehensive scoring equation (Song et al., 2017).

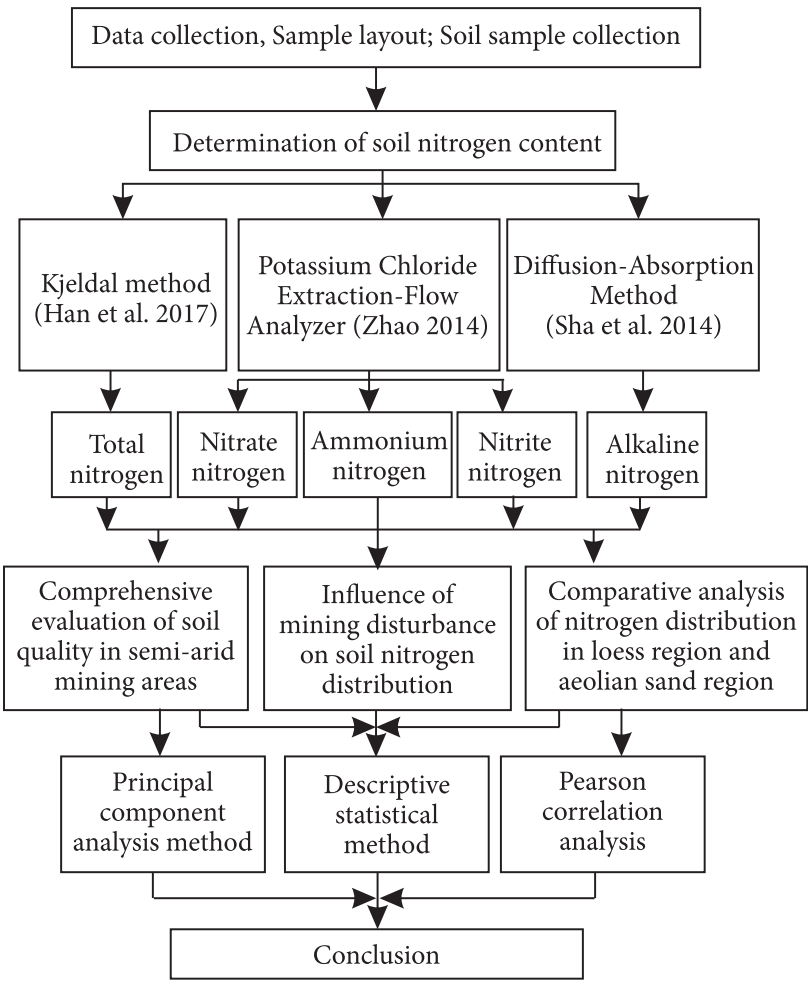

Figure 3. The flow chart of the methodology for this study

$$
I F I=\lambda_{1} F_{1}+\lambda_{2} F_{2}+\ldots+\lambda_{m} F_{m},
$$

where IFI is the integrated soil quality indices value of each sampling point, $\lambda_{1}$ is the corresponding principal component contribution rate, $F_{1}$ is the single principal component comprehensive score.

\section{Results and discussion}

\subsection{The comprehensive evaluation of soil quality in the loess region}

The characteristic values and variances were analyzed for five forms of soil nitrogen in the loess region and the characteristic value which was greater than one was selected. The characteristic values and variance contribution rates of soil nitrogen in the loess region are shown in Table 1. From Table 1, it can be seen that the variance contribution rates reached $83.21 \%$ for the three indicators, indicating that the comprehensive information of soil nitrogen can be reflected by the three indicators in the loess region. According to the matrix of component score coefficients, the comprehensive scores of the three principal components can be calculated, and the linear equations of the single principal component comprehensive score are as follows:

$$
\begin{aligned}
& F_{1}=0.58 X_{1}+0.10 X_{2}+0.53 X_{3}+0.05 X_{4}-0.16 X_{5} ; \\
& F_{2}=-0.11 X_{1}+0.51 X_{2}-0.01 X_{3}+0.03 X_{4}+0.65 X_{5} ; \\
& F_{3}=0.09 X_{1}-0.23 X_{2}-0.02 X_{3}+0.91 X_{4}+0.20 X_{5} ; \\
& I F I=0.368 F_{1}+0.249 F_{2}+0.215 F_{3} .
\end{aligned}
$$


According to equation (5), the comprehensive score of soil sample in the loess region can be calculated. The comprehensive scores of soil samples in the loess region are shown in Table 2. From Table 2, it can be seen that the comprehensive score of different zones was the highest in the NLS-zone. The comprehensive score of soil quality was the lowest in the ZX-zone. The comprehensive score of soil quality in the loess region was as follows: NLS > WLS $>$ YS $>$ ZX.

Table 1. Characteristic values and variance contribution rates (the loess region)

\begin{tabular}{|c|c|c|c|c|c|c|}
\hline \multirow[b]{2}{*}{ 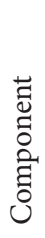 } & \multicolumn{3}{|c|}{ Initial feature value } & \multicolumn{3}{|c|}{ Rotated square sum } \\
\hline & Sum & $\begin{array}{c}\text { Variance } \\
\text { contri- } \\
\text { bution } \\
\text { rate } \%\end{array}$ & $\begin{array}{l}\text { Cumu- } \\
\text { lative } \\
\text { contri- } \\
\text { bution } \\
\text { rate } \%\end{array}$ & Sum & $\begin{array}{c}\text { Variance } \\
\text { contri- } \\
\text { bution } \\
\text { rate } \%\end{array}$ & $\begin{array}{c}\text { Cumu- } \\
\text { lative } \\
\text { contri- } \\
\text { bution } \\
\text { rate\% }\end{array}$ \\
\hline 1 & 1.840 & 36.790 & 36.790 & 1.568 & 31.358 & 31.358 \\
\hline 2 & 1.244 & 24.886 & 61.677 & 1.504 & 30.082 & 61.440 \\
\hline 3 & 1.077 & 21.535 & 83.212 & 1.089 & 21.772 & 83.212 \\
\hline 4 & 0.507 & 10.141 & 93.353 & & & \\
\hline 5 & 0.332 & 6.647 & 100.000 & & & \\
\hline
\end{tabular}

Table 2. The comprehensive scores of different zones in the loess region

\begin{tabular}{|c|c|c|}
\hline & Range & Average \\
\hline ZX & $6.66 \sim 20.36$ & 12.90 \\
\hline YS & $8.00 \sim 25.18$ & 13.54 \\
\hline NLS & $9.43 \sim 33.81$ & 17.99 \\
\hline WLS & $11.76 \sim 19.69$ & 15.26 \\
\hline
\end{tabular}

\subsection{The effect of coal mining on soil nitrogen in the loess region in 2015}

Table 3 shows statistical analysis of nitrogen forms and contents in soil of the loess region (2015). From Table 3, it could be seen that, the change ranges of soil total nitrogen and alkaline nitrogen content were the largest in ZX-zone, with the values being $0.95 \mathrm{~g} / \mathrm{kg}$ and $55.12 \mathrm{mg} / \mathrm{kg}$, respectively. The change range of soil nitrogen content was the smallest in NLS-zone. The smallest change range values of soil total nitrogen and alkaline nitrogen were $0.45 \mathrm{~g} / \mathrm{kg}$ and $25.72 \mathrm{mg} / \mathrm{kg}$ in NLS-zone, respectively. The average of total nitrogen content decreased in the sequence of the ZX, WLS, NLS and YS. For alkaline nitrogen, the average decreased in the sequence of WLS-zone, ZX-zone, NLSzone and YS-zone. It was proved that soil nitrogen content was the lowest in YS-zone in the loess region. It could be seen that the coefficients of variation of soil total nitrogen and alkaline nitrogen were the largest in YS-zone of the loess region. The coefficient of variation of soil total nitrogen was larger than that of alkaline nitrogen in the loess region.
Table 3. Statistical analysis of nitrogen forms and contents in soil of the loess region (2015)

\begin{tabular}{|c|c|c|c|c|c|c|}
\hline & $\begin{array}{l}\text { Nitrogen } \\
\text { forms }\end{array}$ & $\begin{array}{l}\text { Mini- } \\
\text { mum }\end{array}$ & $\begin{array}{l}\text { Maxi- } \\
\text { mum }\end{array}$ & $\begin{array}{l}\text { Ave- } \\
\text { rage }\end{array}$ & SD & CV\% \\
\hline \multirow{2}{*}{ ZX } & $\begin{array}{l}\text { Total } \\
\text { nitrogen } \\
\mathrm{g} / \mathrm{kg}\end{array}$ & 0.41 & 1.36 & 0.73 & 0.36 & 49.17 \\
\hline & $\begin{array}{l}\text { Alkaline } \\
\text { nitrogen } \\
\text { mg/kg }\end{array}$ & 25.73 & 80.85 & 45.94 & 21.14 & 46.02 \\
\hline \multirow{2}{*}{ YS } & $\begin{array}{l}\text { Total } \\
\text { nitrogen } \\
\mathrm{g} / \mathrm{kg}\end{array}$ & 0.21 & 0.80 & 0.41 & 0.20 & 49.77 \\
\hline & $\begin{array}{l}\text { Alkaline } \\
\text { nitrogen } \\
\text { mg/kg }\end{array}$ & 14.70 & 40.43 & 30.01 & 15.31 & 51.02 \\
\hline \multirow[b]{2}{*}{ NLS } & $\begin{array}{l}\text { Total nitro- } \\
\text { gen } \mathrm{g} / \mathrm{kg}\end{array}$ & 0.35 & 0.80 & 0.58 & 0.16 & 28.49 \\
\hline & $\begin{array}{l}\text { Alkaline } \\
\text { nitrogen } \\
\mathrm{mg} / \mathrm{kg}\end{array}$ & 25.73 & 51.45 & 40.43 & 9.58 & 23.71 \\
\hline \multirow{2}{*}{ WLS } & $\begin{array}{l}\text { Total } \\
\text { nitrogen } \\
\mathrm{g} / \mathrm{kg}\end{array}$ & 0.37 & 0.86 & 0.72 & 0.18 & 24.62 \\
\hline & $\begin{array}{l}\text { Alkaline } \\
\text { nitrogen } \\
\text { mg/kg }\end{array}$ & 33.08 & 73.50 & 53.29 & 13.30 & 24.96 \\
\hline \multirow{2}{*}{$\begin{array}{l}\text { Loess } \\
\text { region }\end{array}$} & $\begin{array}{l}\text { Total } \\
\text { nitrogen } \\
\mathrm{g} / \mathrm{kg}\end{array}$ & 0.21 & 1.36 & 0.61 & 0.26 & 42.56 \\
\hline & $\begin{array}{l}\text { Alkaline } \\
\text { nitrogen } \\
\mathrm{mg} / \mathrm{kg}\end{array}$ & 14.70 & 80.85 & 42.42 & 16.79 & 39.58 \\
\hline
\end{tabular}

\subsection{The effect of coal mining on soil nitrogen in the loess region in 2016}

Table 4 shows statistical analysis of nitrogen forms and contents in soil of the loess region (2016). From Table 4, it could be seen that, for different nitrogen forms, the sequence of total nitrogen content, ammonium nitrogen content, nitrate nitrogen content, nitrite nitrogen content and alkaline nitrogen content in different regions were as follows: WLS $>$ NLS $>$ ZX $>$ YS, NLS $>$ YS $>$ ZX $>$ WLS, NLS $>$ WLS $>$ ZX $>$ YS, WLS $>$ NLS $>$ YS $>$ ZX and NLS $>$ $\mathrm{YS}>\mathrm{WLS}>\mathrm{ZX}$. For total nitrogen and nitrate nitrogen, the averages content of soil nitrogen were the lowest in YS-zone than that in other three zones of the loess region in 2016. For nitrite nitrogen and alkaline nitrogen, the averages content of soil nitrogen were the lowest in ZXzone. For ammonium nitrogen, the average content was the lowest in WLS-zone than that in other three zones in the loess region. The order of nitrogen mean values in $\mathrm{ZX}$ zone, YS-zone, NLS-zone and WLS-zone were as follows: total nitrogen $>$ alkaline nitrogen $>$ ammonium nitrogen $>$ nitrate nitrogen $>$ nitrite nitrogen. We can see that, for the loess region, the coefficient of variation of soil nitrogen was in the sequence of alkaline nitrogen $>$ nitrate nitrogen $>$ total nitrogen $>$ ammonium nitrogen $>$ nitrite nitrogen. 
Table 4. Statistical analysis of nitrogen forms and contents in soil of the loess region (2016)

\begin{tabular}{|c|c|c|c|c|c|c|}
\hline & nitrogen forms & Minimum & Maximum & Average & SD & $\mathrm{CV} \%$ \\
\hline \multirow{5}{*}{$\mathrm{ZX}$} & Total nitrogen $\mathrm{g} / \mathrm{kg}$ & 0.11 & 0.62 & 0.33 & 0.17 & 51.68 \\
\hline & Ammonium nitrogen $\mathrm{mg} / \mathrm{kg}$ & 5.88 & 9.24 & 7.74 & 1.22 & 15.74 \\
\hline & Nitrate nitrogen $\mathrm{mg} / \mathrm{kg}$ & 2.29 & 5.97 & 3.62 & 1.35 & 37.21 \\
\hline & Nitrite nitrogen $\mathrm{mg} / \mathrm{kg}$ & 0.36 & 0.37 & 0.36 & 0.01 & 1.69 \\
\hline & Alkaline nitrogen $\mathrm{mg} / \mathrm{kg}$ & 22.05 & 36.75 & 30.63 & 6.00 & 19.60 \\
\hline \multirow{5}{*}{ YS } & Total nitrogen $\mathrm{g} / \mathrm{kg}$ & 0.15 & 0.49 & 0.26 & 0.13 & 49.81 \\
\hline & Ammonium nitrogen $\mathrm{mg} / \mathrm{kg}$ & 5.84 & 17.15 & 9.59 & 4.40 & 45.84 \\
\hline & Nitrate nitrogen $\mathrm{mg} / \mathrm{kg}$ & 2.20 & 6.71 & 3.54 & 1.62 & 45.85 \\
\hline & Nitrite nitrogen $\mathrm{mg} / \mathrm{kg}$ & 0.36 & 0.41 & 0.39 & 0.02 & 5.00 \\
\hline & Alkaline nitrogen $\mathrm{mg} / \mathrm{kg}$ & 25.73 & 80.85 & 43.49 & 21.73 & 49.97 \\
\hline \multirow{5}{*}{ NLS } & Total nitrogen $\mathrm{g} / \mathrm{kg}$ & 0.18 & 0.57 & 0.37 & 0.17 & 45.76 \\
\hline & Ammonium nitrogen $\mathrm{mg} / \mathrm{kg}$ & 6.29 & 18.66 & 10.67 & 4.70 & 44.29 \\
\hline & Nitrate nitrogen $\mathrm{mg} / \mathrm{kg}$ & 3.40 & 5.84 & 4.08 & 1.06 & 26.02 \\
\hline & Nitrite nitrogen $\mathrm{mg} / \mathrm{kg}$ & 0.38 & 0.41 & 0.39 & 0.01 & 3.13 \\
\hline & Alkaline nitrogen $\mathrm{mg} / \mathrm{kg}$ & 29.40 & 128.63 & 56.96 & 37.89 & 66.52 \\
\hline \multirow{5}{*}{ WLS } & Total nitrogen $\mathrm{g} / \mathrm{kg}$ & 0.33 & 0.54 & 0.42 & 0.08 & 19.51 \\
\hline & Ammonium nitrogen $\mathrm{mg} / \mathrm{kg}$ & 5.85 & 8.38 & 7.08 & 1.13 & 15.95 \\
\hline & Nitrate nitrogen $\mathrm{mg} / \mathrm{kg}$ & 2.52 & 5.87 & 3.87 & 1.48 & 38.38 \\
\hline & Nitrite nitrogen $\mathrm{mg} / \mathrm{kg}$ & 0.37 & 0.42 & 0.40 & 0.02 & 4.40 \\
\hline & Alkaline nitrogen $\mathrm{mg} / \mathrm{kg}$ & 25.73 & 44.10 & 34.3 & 6.44 & 18.76 \\
\hline \multirow{5}{*}{$\begin{array}{l}\text { Loess } \\
\text { region }\end{array}$} & Total nitrogen $\mathrm{g} / \mathrm{kg}$ & 0.11 & 0.62 & 0.34 & 0.15 & 42.31 \\
\hline & Ammonium nitrogen $\mathrm{mg} / \mathrm{kg}$ & 5.84 & 18.66 & 8.77 & 3.43 & 39.17 \\
\hline & Nitrate nitrogen $\mathrm{mg} / \mathrm{kg}$ & 2.20 & 6.71 & 3.78 & 1.96 & 51.92 \\
\hline & Nitrite nitrogen $\mathrm{mg} / \mathrm{kg}$ & 0.36 & 0.42 & 0.38 & 0.02 & 4.97 \\
\hline & Alkaline nitrogen $\mathrm{mg} / \mathrm{kg}$ & 22.05 & 128.63 & 37.55 & 23.22 & 56.17 \\
\hline
\end{tabular}

\subsection{Comparisons of soil nitrogen in the loess region between 2015 and 2016}

Figure 4 shows the comparisons of soil nitrogen content in different regions of the loess region between 2015 and 2016. From Figure 4, generally speaking, we can see that the total nitrogen content of 2015 was greater than that of 2016 except two sampling locations NLS-4 and WLS-4. The results showed that the total nitrogen content gradually decreased with time. This was consistent with Jing et al. (2018) research conclusions. Jing et al. (2018) considered the loss of soil total nitrogen significantly in subsided areas. Because of the variation in physical properties resulted from land subsidence, the soil micro environment arisen chain reaction, which leaded to the reduce of the biological activity and the variation in soil nutrients in vertical and horizontal directions (Jing et al., 2018). The trend of total nitrogen content change at the six sampling locations in 2015 was consistent with that in 2016. For alkaline nitrogen, it was proved that, except two sampling locations ZX-6 and WLS-4, the content of alkaline nitrogen in 2015 was greater than that of 2016 in ZX-zone and WLS-zone.
But in YS-zone and NLS-zone, the result showed that the alkaline nitrogen content in 2015 was lesser than that in 2016 except three sampling locations YS-4, NLS-3 and NLS-6. According to Figure 4, Table 4 and Table 5, it could be seen that the averages of total nitrogen and alkaline nitrogen in 2015 were $0.61 \mathrm{~g} / \mathrm{kg}$ and $42.42 \mathrm{mg} / \mathrm{kg}$, respectively. The averages of total nitrogen content and alkaline nitrogen content in 2016 were $0.34 \mathrm{~g} / \mathrm{kg}$ and $41.34 \mathrm{mg} / \mathrm{kg}$, respectively. The results showed that the loss of nitrogen increased with time in the mining area, in which the total nitrogen loss was $0.27 \mathrm{~g} / \mathrm{kg}$, and the alkaline nitrogen loss was $1.08 \mathrm{mg} / \mathrm{kg}$.

\subsection{Relationships between different forms of soil nitrogen in the loess region}

Figure 5 shows the relationships between different forms of soil nitrogen in the loess region. From Figure 5, the nitrate nitrogen content increased with the increase of the total nitrogen content. Between ammonium nitrogen and alkaline nitrogen, with ammonium nitrogen content increasing, alkaline nitrogen content increased. 

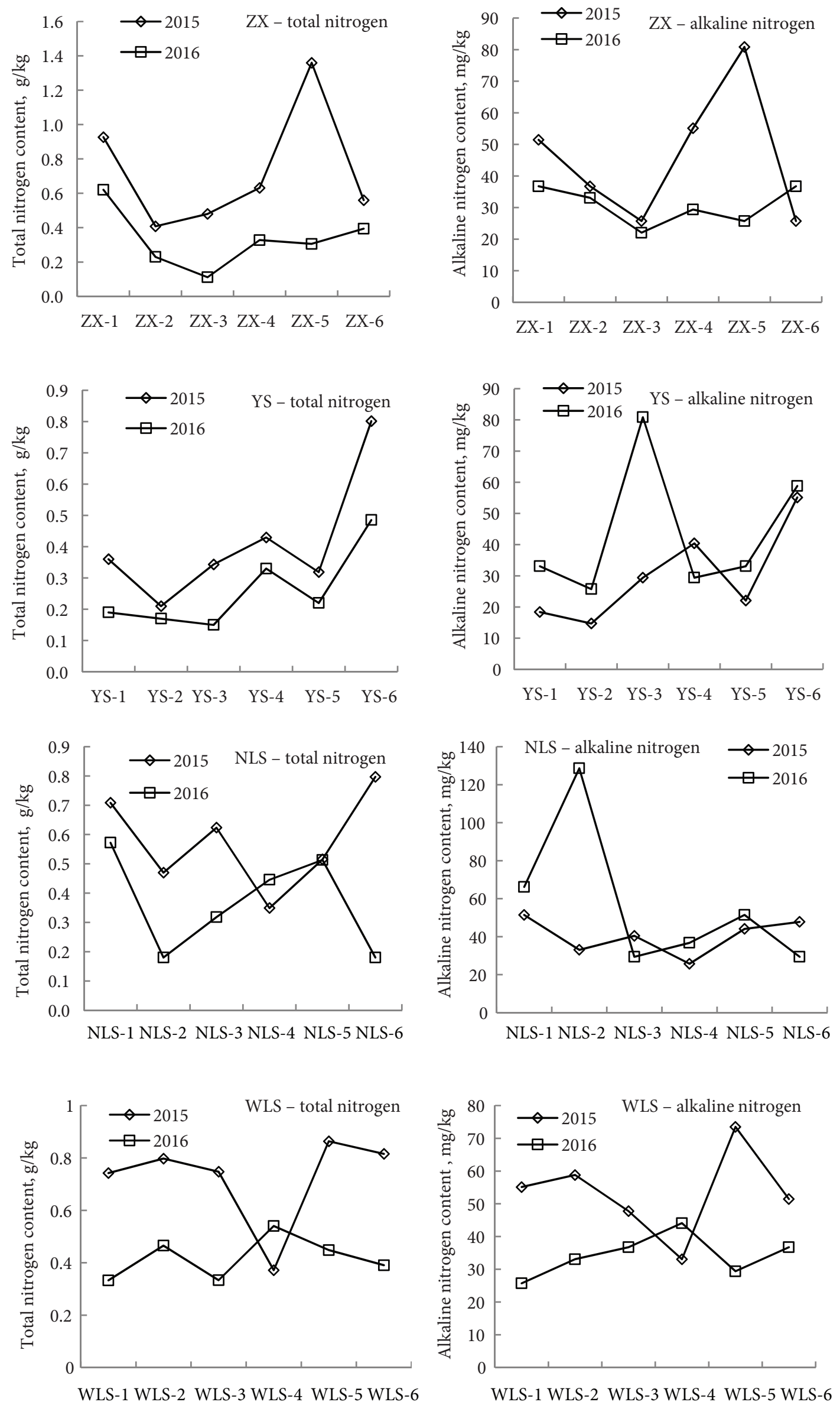

Figure 4 .The comparisons of soil nitrogen content in different regions of the loess region between 2015 and 2016 

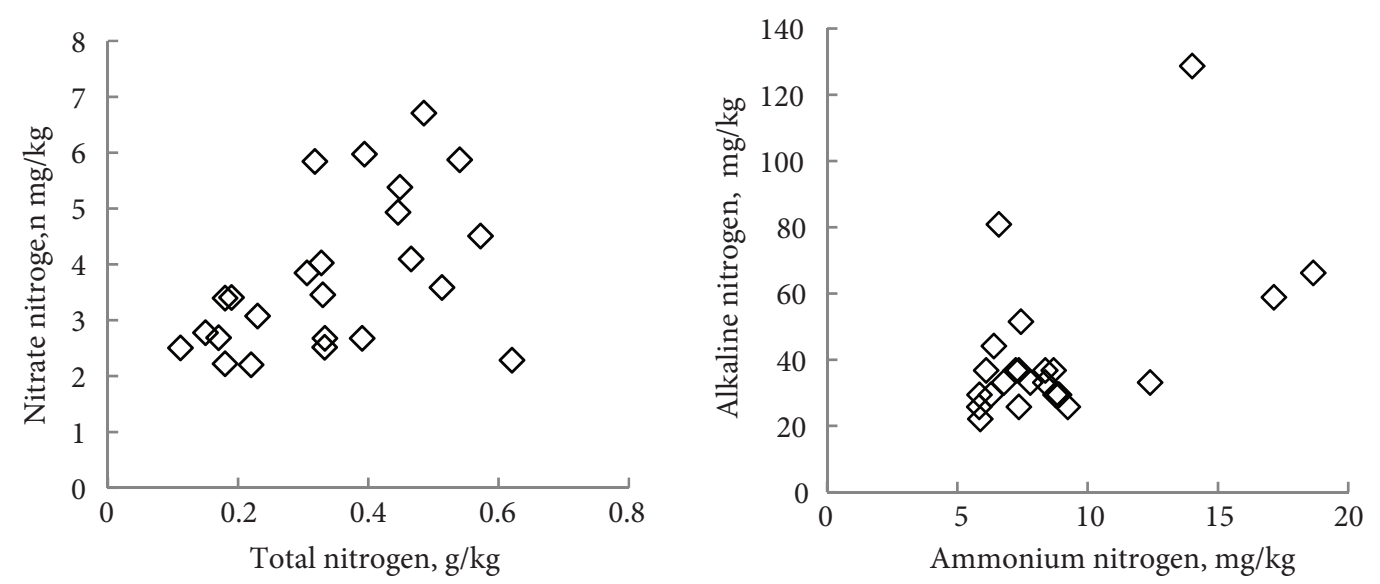

Figure 5. The relationships between different forms of soil nitrogen in the loess region

\subsection{The comprehensive evaluation of soil quality in the aeolian sand region}

The characteristic values and variance contribution rates of soil nitrogen in the aeolian sand region are shown in Table 5. From the analysis of characteristic values and variances, we can see that the variance contribution rates of the three indicators reached $87.96 \%$, which can reflect the comprehensive information of soil nitrogen in the aeolian sand region.

Table 6. The comprehensive scores of different zones in the aeolian sand region

\begin{tabular}{|c|c|c|}
\hline & Range & Average \\
\hline FC & $5.56 \sim 23.75$ & 13.73 \\
\hline ZX & $10.68 \sim 16.98$ & 13.60 \\
\hline YS & $10.70 \sim 13.64$ & 12.20 \\
\hline NLS & $7.54 \sim 19.64$ & 12.48 \\
\hline WLS & $15.85 \sim 32.00$ & 25.56 \\
\hline
\end{tabular}

According to the matrix of component score coefficients, the comprehensive scores of the three principal components can be calculated. The linear equations of the single principal component comprehensive score are as follows:

$$
\begin{aligned}
& F_{1}=0.57 X_{1}-0.01 X_{2}-0.06 X_{3}+0.59 X_{4} \\
& F_{2}=0.10 X_{1}+0.98 X_{2}-0.05 X_{3}-0.10 X_{4} \\
& F_{3}=0.01 X_{1}-0.05 X_{2}+1.00 X_{3}-0.09 X_{4} \\
& I F I=0.386 F_{1}+0.269 F_{2}+0.225 F_{3} .
\end{aligned}
$$

From equation (9), the comprehensive score of soil sample in the aeolian sand region can be calculated. The comprehensive scores of different zones in the aeolian sand region are shown in Table 6. From Table 6, it can be seen that the comprehensive score of soil quality in FCzone is larger than that in coal mining disturbance area except the WLS-zone. It indicated that the disturbance of coal mining reduced the comprehensive score of soil quality in aeolian sand region. The comprehensive score of soil quality in the aeolian sand region was as follows: WLS >

\begin{tabular}{|c|c|c|c|c|c|c|}
\hline \multirow[b]{2}{*}{ 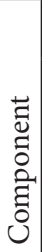 } & \multicolumn{3}{|c|}{ Initial feature value } & \multicolumn{3}{|c|}{ Rotated square sum } \\
\hline & Sum & $\begin{array}{c}\text { Variance } \\
\text { contri- } \\
\text { bution } \\
\text { rate } \%\end{array}$ & $\begin{array}{l}\text { Cumu- } \\
\text { lative } \\
\text { contri- } \\
\text { bution } \\
\text { rate\% }\end{array}$ & Sum & $\begin{array}{c}\text { Variance } \\
\text { contri- } \\
\text { bution } \\
\text { rate } \%\end{array}$ & $\begin{array}{c}\text { Cumu- } \\
\text { lative } \\
\text { contri- } \\
\text { bution } \\
\text { rate } \%\end{array}$ \\
\hline 1 & 1.544 & 38.611 & 38.611 & 1.501 & 37.514 & 37.514 \\
\hline 2 & 1.076 & 26.888 & 65.499 & 1.013 & 25.329 & 62.843 \\
\hline 3 & 0.898 & 22.457 & 87.956 & 1.004 & 25.112 & 87.956 \\
\hline 4 & 0.482 & 12.044 & 100.000 & & & \\
\hline
\end{tabular}
$\mathrm{FC}>\mathrm{ZX}>\mathrm{NLS}>\mathrm{YS}$.

Table 5. Characteristic values and variance contribution rates (the aeolian sand region)

\subsection{The effect of coal mining on soil nitrogen in the aeolian sand region in 2016}

From Table 7, for different nitrogen, total nitrogen average, nitrate nitrogen average, ammonium nitrogen average and alkaline nitrogen average in different regions were in the sequence of WLS $>$ ZX $>$ FC $>$ YS $>$ NLS, YS $>$ WLS $>\mathrm{FC}>\mathrm{NLS}>\mathrm{ZX}, \mathrm{NLS}>\mathrm{ZX}>\mathrm{FC}>\mathrm{WLS}>\mathrm{YS}$ and WLS $>$ NLS $>$ FC $>$ ZX $>$ YS. For total nitrogen and nitrate nitrogen, the content of both changed widely in FC-zone. For ammonium nitrogen and nitrate nitrogen, the content of nitrogen varied widely in NLS-zone, which is consistent with the result of the study in the Loess region. The order of nitrogen average in ZX-zone, YS-zone, NLS-zone, WLS-zone and FC-zone were as follows: total nitrogen > alkaline nitrogen $>$ ammonium nitrogen $>$ nitrate nitrogen. It could be seen that the coefficient of variation of soil nitrogen in the FC-zone was the largest except the alkaline nitrogen. This was also proved by Jing et al. (2018). According to Jing et al. (2018), it can be seen that the 
Table 7. Statistical analysis of nitrogen forms and contents in soil of the aeolian sand region (2016)

\begin{tabular}{|c|c|c|c|c|c|c|}
\hline & Nitrogen forms & Minimum & Maximum & Average & SD & $\mathrm{CV} \%$ \\
\hline \multirow{4}{*}{ FC } & Total nitrogen $\mathrm{g} / \mathrm{kg}$ & 0.11 & 0.49 & 0.29 & 0.19 & 66.14 \\
\hline & Ammonium nitrogen $\mathrm{mg} / \mathrm{kg}$ & 2.76 & 8.40 & 5.12 & 2.92 & 57.16 \\
\hline & Nitrate nitrogen $\mathrm{mg} / \mathrm{kg}$ & 0.73 & 4.40 & 1.96 & 2.11 & 107.59 \\
\hline & Alkaline nitrogen $\mathrm{mg} / \mathrm{kg}$ & 11.03 & 47.78 & 26.95 & 18.86 & 69.98 \\
\hline \multirow{4}{*}{$\mathrm{ZX}$} & Total nitrogen $\mathrm{g} / \mathrm{kg}$ & 0.24 & 0.35 & 0.30 & 0.06 & 18.24 \\
\hline & Ammonium nitrogen $\mathrm{mg} / \mathrm{kg}$ & 5.21 & 5.74 & 5.46 & 0.26 & 4.81 \\
\hline & Nitrate nitrogen $\mathrm{mg} / \mathrm{kg}$ & 0.44 & 1.05 & 0.64 & 0.35 & 55.11 \\
\hline & Alkaline nitrogen $\mathrm{mg} / \mathrm{kg}$ & 18.38 & 36.75 & 25.73 & 9.72 & 37.79 \\
\hline \multirow{4}{*}{ YS } & Total nitrogen $\mathrm{g} / \mathrm{kg}$ & 0.23 & 0.28 & 0.25 & 0.03 & 10.03 \\
\hline & Ammonium nitrogen $\mathrm{mg} / \mathrm{kg}$ & 2.71 & 4.82 & 4.07 & 1.19 & 29.13 \\
\hline & Nitrate nitrogen $\mathrm{mg} / \mathrm{kg}$ & 1.66 & 4.36 & 2.84 & 1.38 & 48.75 \\
\hline & Alkaline nitrogen $\mathrm{mg} / \mathrm{kg}$ & 22.05 & 25.73 & 24.5 & 2.12 & 8.66 \\
\hline \multirow{4}{*}{ NLS } & Total nitrogen $\mathrm{g} / \mathrm{kg}$ & 0.13 & 0.22 & 0.19 & 0.05 & 26.28 \\
\hline & Ammonium nitrogen $\mathrm{mg} / \mathrm{kg}$ & 3.40 & 10.44 & 6.19 & 3.74 & 60.37 \\
\hline & Nitrate nitrogen $\mathrm{mg} / \mathrm{kg}$ & 0.73 & 1.47 & 1.22 & 0.42 & 34.65 \\
\hline & Alkaline nitrogen $\mathrm{mg} / \mathrm{kg}$ & 18.38 & 62.48 & 33.08 & 25.46 & 76.98 \\
\hline \multirow{4}{*}{ WLS } & Total nitrogen $\mathrm{g} / \mathrm{kg}$ & 0.46 & 0.83 & 0.68 & 0.19 & 28.52 \\
\hline & Ammonium nitrogen $\mathrm{mg} / \mathrm{kg}$ & 3.57 & 5.01 & 4.51 & 0.82 & 18.13 \\
\hline & Nitrate nitrogen $\mathrm{mg} / \mathrm{kg}$ & 1.23 & 4.12 & 2.19 & 1.66 & 75.88 \\
\hline & Alkaline nitrogen $\mathrm{mg} / \mathrm{kg}$ & 18.13 & 51.45 & 39.2 & 18.13 & 46.25 \\
\hline \multirow{4}{*}{$\begin{array}{l}\text { Aeolian } \\
\text { Sand } \\
\text { Region }\end{array}$} & Total nitrogen $\mathrm{g} / \mathrm{kg}$ & 0.11 & 0.83 & 0.34 & 0.21 & 60.89 \\
\hline & Ammonium nitrogen $\mathrm{mg} / \mathrm{kg}$ & 2.71 & 10.44 & 5.07 & 2.03 & 40.00 \\
\hline & Nitrate nitrogen mg/kg & 0.44 & 4.40 & 1.77 & 1.41 & 79.43 \\
\hline & Alkaline nitrogen $\mathrm{mg} / \mathrm{kg}$ & 11.03 & 62.48 & 29.89 & 15.40 & 51.51 \\
\hline
\end{tabular}

coefficient of variation of soil total nitrogen in unmined plot was larger than that in the other two subsided plots. For the aeolian sand region, the coefficient of variation of soil nitrogen was as follows: nitrate nitrogen $>$ total nitrogen $>$ alkaline nitrogen $>$ ammonium nitrogen.

\subsection{Relationship between different forms of soil nitrogen in the aeolian sand region}

Figure 6 shows the relationship between total nitrogen and alkaline nitrogen in the aeolian sand region. In Figure 6, there was a linear positive correlation between total nitrogen and alkaline nitrogen, although the fitting coefficient was relative low. It indicated that the content of alkaline nitrogen increased with the increase of total nitrogen content.

\subsection{The comparison of nitrogen content in the aeolian sand region and the loess region}

Figure 7 shows the comparison of different forms of nitrogen content in the loess region and the aeolian sand region. From Figure 7, the total nitrogen content, ammonium nitrogen content, nitrate nitrogen content and alkaline nitrogen content in the loess region were greater than that in the aeolian sand region, with the difference being
$2.48 \mathrm{mg} / \mathrm{kg}, 3.70 \mathrm{mg} / \mathrm{kg}, 2.01 \mathrm{mg} / \mathrm{kg}$ and $11.45 \mathrm{mg} / \mathrm{kg}$, respectively. The difference between the loess region and the aeolian sand region was the greatest in alkaline nitrogen content. The level of nitrogen forms was as follows in the loess region and the aeolian sand region: total nitrogen $>$ alkaline nitrogen $>$ ammonium nitrogen $>$ nitrate nitrogen. The result showed that the amount of soil nitrogen content in the loess region was larger than that in the aeolian sand region.

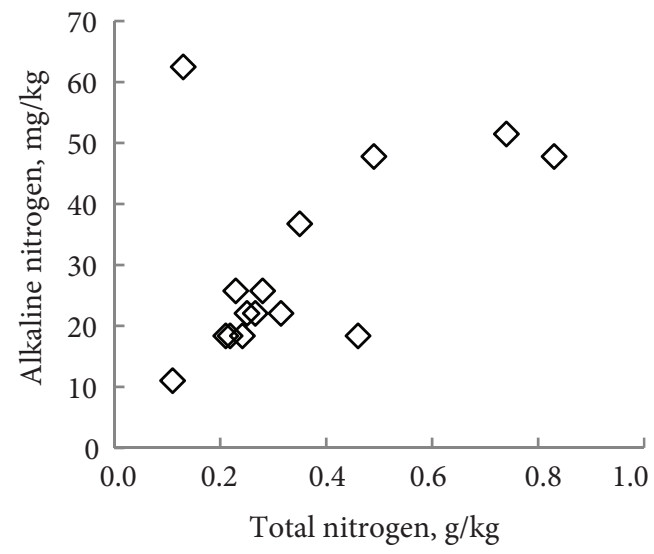

Figure 6. Relationship between total nitrogen and alkaline nitrogen in the aeolian sand region 


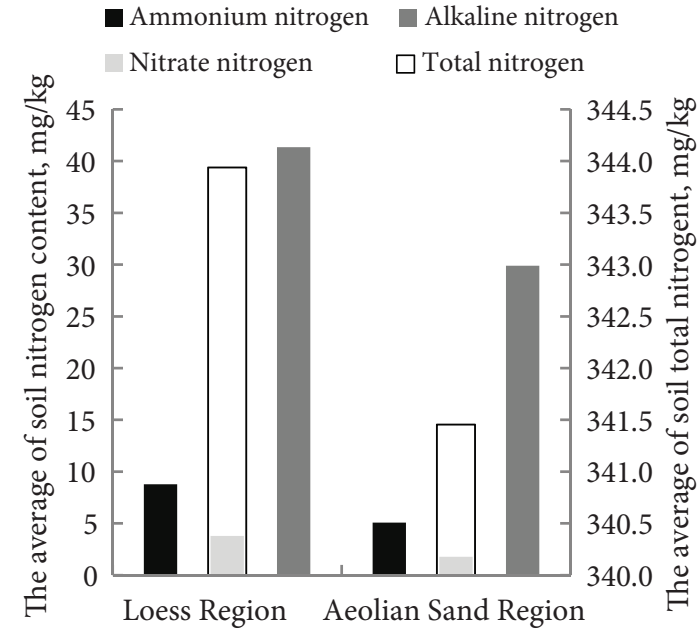

Figure 7. The comparison of different forms of nitrogen content in the loess region and the aeolian sand region

\subsection{The comparison of analysis of correlation between nitrogen forms in the loess region and the aeolian sand region}

PCA was used to analyze the correlation of different soil nitrogen forms in the soil. The results of the PCA are shown in Table 8. The results showed that there was a significant positive correlation between soil total nitrogen and nitrate nitrogen in the loess region, and the correlation coefficient was 0.490 . There was a very significant positive correlation between ammonium nitrogen and alkaline nitrogen, with a correlation coefficient of 0.516 . There was a significant positive correlation between total nitrogen and alkaline nitrogen in the aeolian sand region, with a correlation coefficient being 0.501 . There was no significant correlation between other nitrogen forms.

\section{Conclusions}

This study investigated the effect of coal mining on soil nitrogen and the related relationships in the loess region and the aeolian sand region of semi-arid mining area. The results are as following:

1) The comprehensive score of soil quality in the loess region was as follows: NLS $>$ WLS $>$ YS $>$ ZX. In the aeolian sand region, the comprehensive score of soil quality was as follows: WLS $>$ FC $>$ ZX $>$ NLS > YS.

2) The content of soil total nitrogen in YS-zone was the lowest in the loess region. Moreover, the loss of nitrogen increased with time in the mining area, in which the total nitrogen loss at the depth of $0-15 \mathrm{~cm}$ was $0.27 \mathrm{~g} / \mathrm{kg}$, and the alkaline nitrogen loss at the depth of $0-15 \mathrm{~cm}$ was $1.08 \mathrm{mg} / \mathrm{kg}$.

3) The amount of soil nitrogen content in loess region was larger than that in the aeolian sand region.

4) Based on PCA, it was found that for the loess region, the relationship between total nitrogen and nitrate nitrogen showed a significant positive
Table 8. Analysis of correlation between nitrogen forms

\begin{tabular}{|c|c|c|c|c|c|c|}
\hline & $\begin{array}{l}\text { Pearson } \\
\text { correlation }\end{array}$ & $\begin{array}{l}\text { Total } \\
\text { nitro- } \\
\text { gen } \\
\text { g/kg }\end{array}$ & $\begin{array}{l}\text { Ammo- } \\
\text { nium } \\
\text { nitrogen } \\
\mathrm{mg} / \mathrm{kg}\end{array}$ & $\begin{array}{c}\text { Nitrate } \\
\text { nitro- } \\
\text { gen } \\
\mathrm{mg} / \mathrm{kg}\end{array}$ & $\begin{array}{l}\text { Nitrite } \\
\text { nitro- } \\
\text { gen } \\
\mathrm{mg} / \mathrm{kg}\end{array}$ & $\begin{array}{c}\text { Alka- } \\
\text { line } \\
\text { nitro- } \\
\text { gen } \\
\mathrm{mg} / \mathrm{kg}\end{array}$ \\
\hline \multirow{5}{*}{ 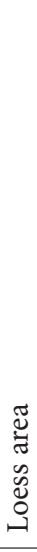 } & $\begin{array}{l}\text { Total } \\
\text { nitrogen } \mathrm{g} / \mathrm{kg}\end{array}$ & 1 & & & & \\
\hline & $\begin{array}{l}\text { Ammonium } \\
\text { nitrogen } \\
\mathrm{mg} / \mathrm{kg}\end{array}$ & 0.253 & 1 & & & \\
\hline & $\begin{array}{l}\text { Nitrate } \\
\text { nitrogen } \\
\mathrm{mg} / \mathrm{kg}\end{array}$ & $0.490^{*}$ & 0.307 & 1 & & \\
\hline & $\begin{array}{l}\text { Nitrite } \\
\text { nitrogen } \\
\mathrm{mg} / \mathrm{kg}\end{array}$ & 0.054 & -0.199 & -0.033 & 1 & \\
\hline & $\begin{array}{l}\text { Alkaline } \\
\text { nitrogen } \\
\mathrm{mg} / \mathrm{kg} \\
\end{array}$ & -0.028 & $0.516^{* *}$ & 0.078 & 0.120 & 1 \\
\hline \multirow{4}{*}{ 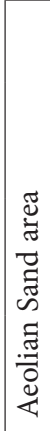 } & $\begin{array}{l}\text { Total } \\
\text { nitrogen } \mathrm{g} / \mathrm{kg}\end{array}$ & 1 & & & & \\
\hline & \begin{tabular}{|l} 
Ammonium \\
nitrogen \\
$\mathrm{mg} / \mathrm{kg}$ \\
\end{tabular} & 0.071 & 1 & & & \\
\hline & \begin{tabular}{|l} 
Nitrate \\
nitrogen \\
$\mathrm{mg} / \mathrm{kg}$ \\
\end{tabular} & 0.140 & 0.086 & 1 & & \\
\hline & $\begin{array}{l}\text { Alkaline } \\
\text { nitrogen } \\
\mathrm{mg} / \mathrm{kg}\end{array}$ & $0.501^{\star}$ & -0.050 & 0.069 & - & 1 \\
\hline
\end{tabular}

Note: ${ }^{\star}$ Significantly correlated at the 0.05 level (both sides);

** Significantly correlated at the 0.01 level (both sides).

correlation. It also was a significant positive correlation between ammonium nitrogen and alkaline nitrogen. In the aeolian sand region, there was a significant positive correlation between total nitrogen and alkaline nitrogen. There was no significant correlation among other nitrogen forms.

The results of this study showed the quantitative impact on soil nitrogen by the subsidence of coal mining, understood the distribution of nitrogen content in two typical landforms in semi-arid mining area, and defined the soil quality of each deformation zone. However, soil nitrogen was considered during small time scale in this study. For the further studies, other soil chemical index can be considered during large time scale. And the studies on impact of soil quality by coal mining should be paid more attentions for the further study.

\section{Recommendations}

In order to reduce the impact of coal mining on soil nitrogen distribution and improve soil quality in semi-arid mining area, coal enterprises should exploit the coal appropriately and carry out reclamation work on the land 
after coal mining. Vegetation planting is a good method to restore land ecological diversity, and reduce water loss and soil erosion.

\section{Acknowledgments}

The work was supported by "the Fundamental Research Funds for the Central Universities” (No. 2017XKQY072).

\section{References}

Bian, Z. F., Lei, S. G., Inyang, H. I., Chang, L. Q., Zhang, R. C., Zhou, C. J., \& He, X. (2009). Integrated method of RS and GPR for monitoring the changes in the soil moisture and groundwater environment due to underground coal mining. Environmental Geology, 57(1), 131-142. https://doi.org/10.1007/s00254-008-1289-X

Bian, Z. F., Inyang, H. I., Daniels, J. L., Otto, F., \& Struthers, S. (2010). Environmental issues from coal mining and their solutions. Mining Science Technology, 20(2), 0215-0223. https://doi.org/10.1016/S1674-5264(09)60187-3

Cachoa, J. F., Youssef, M. A., Shi, W., Chescheir, G. M., Skaggs, R. W., Tian, S. Y., Leggett, Z. H., Sucre, E. B., Nettles, J. E., \& Arellano, C. (2018). Impacts of forest-based bioenergy feedstock production on soil nitrogen cycling. Forest Ecology \& Management, 419, 227-239. https://doi.org/10.1016/j.foreco.2018.04.002

Endale, D. M., Potter, T. L., Strickland, T. C., \& Bosch, D. D. (2017). Sediment-bound total organic carbon and total organic nitrogen losses from conventional and strip tillage cropping systems. Soil \& Tillage Research, 171, 25-34. https://doi.org/10.1016/j.still.2017.04.004

He, G., Yang, L., Ling, G., Jia, F., \& Hong, D. (1991). Mining's subsidence (pp. 81-82). Xuzhou, Jiangsu Province, China: China University of Mining and Technology Press.

Han, C. C., Yang, Y., Liu, B. R., Xie, Y. Z., \& Wang, L. J. (2017). Effect of enclosure years on soil organic carbon, total nitrogen, total phosphorus and microbial biomass carbon and nitrogen in desert steppe. Jiangsu Agricultural Sciences, 45(16), 260-263.

He, Y. M., He, X., Liu, Z. R., Zhao, S. W., Bao, L. Y., Li, Q., \& Yan, L. (2017). Coal mine subsidence has limited impact on plant assemblages in an arid and semi-arid region of northwestern China. Ecoscience, 24(3-4), 91-103.

https://doi.org/10.1080/11956860.2017.1369620

Iwaoka, C., Imada, S., Taniguchi, T., Du, S., Yamanaka, N., \& Tatenno, R. (2018). The impacts of soil fertility and salinity on soil nitrogen dynamics mediated by the soil microbial community beneath the halophytic shrub tamarisk. Microbial Ecology, 75(4), 985-996.

https://doi.org/10.1007/s00248-017-1090-z

Jarašiūnas, G., \& Kinderienè, I. (2016). Impact of agro-environmental systems on soil erosion processes and soil properties on hilly landscape in western Lithuania. Journal of Environmental Engineering \& Landscape Management, 24(1), 60-69. https://doi.org/10.3846/16486897.2015.1054289

Jing, Z. R., Wang, J. M., Zhu, Y. C., \& Feng, Y. (2018). Effects of land subsidence resulted from coal mining on soil nutrient distributions in a loess region of China. Journal of Cleaner Production, 177, 350-361.

https://doi.org/10.1016/j.jclepro.2017.12.191

Kuter, N., Dilaver, Z., \& Gul, E. (2014). Determination of suitable plant species for reclamation at an abandoned coal mine area. International Journal of Surface Mining, Reclamation \& Environment, 28(5), 268-276.

https://doi.org/10.1080/17480930.2014.932940

Kolbe, S. E., Miller, A. I., Townsend-Small, A., Cameron, G. N., \& Culley, T. M. (2016). Impact of land-use history and forest trees on soil organic carbon and nitrogen stocks. Soil Science Society of America Journal, 80(4), 1089-1097.

https://doi.org/10.2136/sssaj2015.12.0426

Liu, Z. J., Zhou, W., Shen, J. B., He, P., Lei, Q. L., \& Liang, G. Q. (2014). A simple assessment on spatial variability of rice yield and selected soil chemical properties of paddy fields in South China. Geoderma, 235, 39-47.

https://doi.org/10.1016/j.geoderma.2014.06.027

Liu, H., Deng, K. Z., Lei, S. G., \& Bian, Z. F. (2015). Mechanism of formation of sliding ground fissure in loess hilly areas caused by underground mining. International Journal of Mining Science \& Technology, 25(4), 553-558.

https://doi.org/10.1016/j.ijmst.2015.05.006

Masilionytė, L., Maikštėnienė, S., Velykis, A., \& Satkus, A. (2014). Agroecosystems to decrease diffuse nitrogen pollution in Northern Lithuania. Journal of Environmental Engineering \& Landscape Management, 22(3), 194-207. https://doi.org/10.3846/16486897.2013.860898

Muhammed, S. E., Coleman, K., Wu, L. H., Bell, V. A., Davies, J. A. C., Quinton, J. N., Carnell, E. J., Tomlinson, S. J., Dore, A. J., \& Dragosits, U. (2018). Impact of two centuries of intensive agriculture on soil carbon, nitrogen and phosphorus cycling in the UK. Science of the Total Environment, 634, 1486-1504.

https://doi.org/10.1016/j.scitotenv.2018.03.378

Sun, H. X. (2008). Rules comparison of surface movement induced by coal mining under Aeolian sand and loess. Coal Mining Technology, 13(1), 6-9.

Sha, N., Zhang, S. F., Luo, H., Di, C. X., Nie, J., Li, X. P., \& Lian, H. F. (2014). Comparison two kinds of determination method of soil alkaline hydrolysis nitrogen. Inner Mongolia Agricultural and Technology, (6), 25-26.

Shi, P. L., Zhang, Y. X., Hu, Z. Q., Ma, K., \& Yu, B. B. (2017a). Influence mechanism of coal mining subsidence on soil quality and restoration measures in west China Aeolian sand area. Journal of University of Chinese Academy of Sciences, 34(3), 318-328.

Shi, P. L., Zhang, Y. X., Hu, Z. Q., Ma, K., Wang, H., \& Chai, T. Y. (2017b). The response of soil bacterial communities to mining subsidence in the west China aeolian sand area. Applied Soil Ecology, 121, 1-10. https://doi.org/10.1016/j.apsoil.2017.09.020

Song, Q. F., Niu, S. Z., Chen, Z. W., Yin, J., Zhou, S. J., \& Cen, C. J. (2017). Evaluation of nutrient status in site soil of ancient tea trees in Huaxi on principal component analysis. Acta Agriculturae Zhejiangensis, 29(11), 1844-1853.

Strachel, R., Wyszkowska, J., \& Baćmaga, M. (2017). The effect of nitrogen on the microbiological and biochemical properties of zinc-contaminated soil. Journal of Environmental Engineering \& Landscape Management, 25(1), 13-22.

https://doi.org/10.3846/16486897.2016.1184154

Wang, J. M., Qin, Q., Hu, S. J., \& Wu, K. N. (2016a). A concrete material with waste coal gangue and fly ash used for farmland drainage in high groundwater level areas. Journal of Cleaner Production, 112, 631-638. https://doi.org/10.1016/j.jclepro.2015.07.138

Wang, T., Kang, F. F., Cheng, X. Q., Han, H. R., Bai, Y. C., \& Ma, J. Y. (2016b). Spatial variability of organic carbon and 
total nitrogen in the soils of a subalpine forested catchment at Mt. Taiyue, China. Catena, 155, 41-52.

https://doi.org/10.1016/j.catena.2017.03.004

Wang, J. M., Wang, P., Qin, Q., \& Wang, H. D. (2017). The effects of land subsidence and rehabilitation on soil hydraulic properties in a mining area in the Loess Plateau of China. Catena, 159, 51-59.

https://doi.org/10.1016/j.catena.2017.08.001

Xiao, K. C., He, T. G., Chen, H., Peng, W. X., Song, T. Q., Wang, K. L., \& Li, D. J. (2017). Impacts of vegetation restoration strategies on soil organic carbon and nitrogen dynamics in a karst area, southwest China. Ecological Engineering, 101, 247-254.

https:///doi.org/10.1016/j.ecoleng.2017.01.037

Yang, D. J., Bian, Z. F., \& Lei, S. G. (2016). Impact on soil physical qualities by the subsidence of coal mining: a case study in western China. Environmental Earth Sciences, 75, 652. https://doi.org/10.1007/s12665-016-5439-2

Zhang, F. W., Hou, X. W., Han, Z. T., Yang, H. F., \& Song, Y. X. (2003). Influence of coal mining collapse on soil quality and protection technology. Geography \& Geographical Information Science, 19(3), 67-70.

Zhao, Y. (2014). Research on storage condition for analysis in determination of nitrogen, nitrite nitrogen and nitrate nitrogen in soil. Arid Environmental Monitoring, 28(4), 182-186.

Zheng, L. H., Pei, J. B., Jin, X. X., Schaeffer, S., An, T. T., \& Wang, J. K. (2018). Impact of plastic film mulching and fertilizers on the distribution of straw-derived nitrogen in a soilplant system based on ${ }^{15} \mathrm{~N}$-labeling. Geoderma, 317, 15-22. https://doi.org/10.1016/j.geoderma.2017.12.020 